\title{
Proliferation of Small Arms and Light Weapons: Challenge to Development, Peace and Security in Africa.
}

\author{
Dr Mrs. Esther Chelule, \\ Egerton University and Njoro
}

\begin{abstract}
The proliferation of small arms and light weapons (SALW) has been caused by many factors. The SALW cannot cause conflict on their own but when used by rebels, it has caused havoc, destruction of lives in the world. There are many manufacturers of SALW in the world where their market is in conflict zones of Africa, especially The Horn of Africa. This paper discusses the factors for arms proliferation, the international interventions, the regional conventions and the arms control.
\end{abstract}

Key Words: Arms Control,Challenges, Effects, Small Arms, Light Weapons, Proliferation

\section{Introduction}

The United Nations General Assembly defines "small arms and light weapons" as any portable lethal weapon that expels or launches, is designed to expel or launch, or may be readily converted to expel or launch a shot, bullet or projectile by the action of an explosive ( Arms Survey 2013; Heinrich,2006).United Nations Institute for Disarmament Research describes small arms to include: revolvers and self-loading pistols; rifles and carbines; sub-machine-guns; assault rifles; light machine-gun; heavy machine-guns; hand-held under-barrel and mounted grenade launchers; portable anti-craft guns; portable anti-tank guns; recoilless rifles; portable launchers of antitank missiles and rockets system; portable launchers of anti-aircraft missiles systems; and mortars of calibers less than 100mm (United Nations Institute for Disarmament Research (UNIDIR,2006). Firearms incorporates barreled and lethal weapon that expels, which is specifically designed to expel or may be readily converted to expel a shot, bullet or projectile by the action of burning propellant. An Antique firearms and their replicas are defined any device which may be readily converted to a weapon as referred to above or destructive for instance explosive bomb, incendiary bomb or gas bomb, grenade, rocket launcher, missiles, missile system or mine (controlarms,2005;Sunday ,E.,2011). Ammunition is the complete round or its components, parts or replacement parts of a small arm or light weapon, provided that those components are themselves subject to authorization of the respective State party.

The definition of "Small arms" refer to weapons meant for individual use, including revolvers and self-loading pistols, rifles and carbines, sub-machine guns, assault rifles and light machine guns. Light weapons on the other hand are portable weapons designed for use by several persons serving as a crew: heavy machine guns, automatic cannons, howitzers, mortars of less than $100 \mathrm{~mm}$ caliber, grenade launchers, anti-tank weapons and launchers, recoilless guns, shoulder fired rockets, anti-aircraft weapons and launchers, and air defense weapons (SADC Firearms Protocol, 2003: Article 1.2).According to Best Practice Guidelines (2005)for the Implementation of the Nairobi Declaration and Nairobi Protocol on Small Arms and Light Weapons, small arms are weapons which are designed for personal use and shall include: light machine guns, including machine pistols, fully automatic rifles and assault rifles and semi-automatic rifles . A light weapon, Man-portable Air Defense System (MANPADS) is referred to as shoulder-fire anti-aircraft missile which the terrorists use to attack aviation anywhere in the world. Small arms and light weapons are a subcategory of conventional weapons and range from pistols and rifles to mortars, rocket-propelled grenades, and man-portable air defense systems, or MANPADS (Conventional Weapons Destruction (CWD)

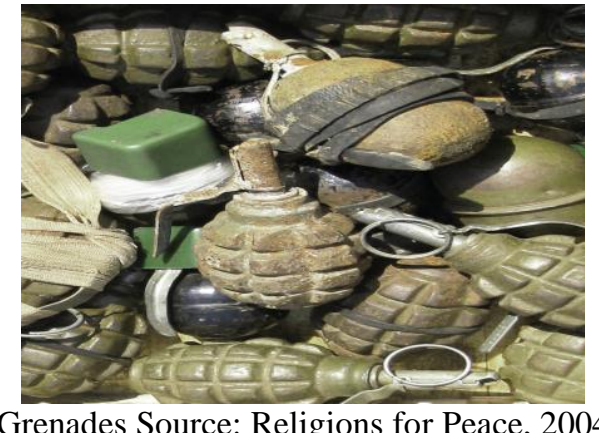

Grenades Source: Religions for Peace, 2004 


\section{Global Small Arms and Light Weapons}

Globally, it is estimated that there are approximately 875 million small arms are in circulation, stockpile and private possession, produced by more than 1,000 companies from nearly 100 countries, and authorized trade exceeds US\$ 8.5 billion(Arms Survey, 2013); of these 200 million belong to the government and state militaries, 26 million are in the hands of law enforcement agencies. The bulk of the global small weapons, which is estimated at two third are held by civilians and non-state actors, and 100million are reported to be in Africa (Africa Union, 2012; Shah A., 2006; Stohl. R., et al (2010). There are also half a billion military small arms around the world; that each year some 300,000 to half a million people around the world are killed by these weapons; $90 \%$ of civilians are casualties by small arms because the civilians get access to purchase more than $80 \%$ of the arms produced in the world and that every minute someone is killed by a gun. It is also reported that 1,134 companies in 98 countries are engaged in the production of small ammunition estimated 5 to 8 million small arms being produced per year and black market trade ranges fromUS\$2-10 billion a year (UNODA() Arms Survey 2009; Shah., A.2006). Indeed as Ali Mazrui put it:

"In a technologically underdeveloped society, in the twentieth century, ultimate power resides not in these who control the means of production (as postulated by Marx), but in these who control the means of destruction (captured by the soldier/bandit with an AK47)." Ali Mazrui (1986)

\section{Africa Sources of SALW}

There is an estimated 2,100 million Small Arms and Light Weapons in Africa (Africa Union). An estimated 70 million to 100 million AK-47 assault rifles have been produced and are found in the national inventories of at least 58 states. .According to the Small Arms Survey (2009), at least 38 companies produce small arms in sub-Saharan Africa, with the largest production facilities located in Africa, the leading being South Africa. Europe is known to have been the chief producer of small arms and light weapons flowing into Africa. There are however other various sources of small arms and light weapons (SALW) proliferation in Africa which include the manufacture and supply of new weapons both inside and outside the continent, adding up to the remnants of weapons, which are shipped into Africa in the 1970s and 1980s and early 1990s by the former Soviet Union, the United States, and their allies to facilitate different interstate and intra-state proxy wars, or the Cold War (Abdel-Fatau, 2011). An estimated 79\% of small arms in Africa are in the hands of civilians and if they get lost or stolen, the same weapons find their way back into the black market adding to the number of weapons in illegal possession. When the Cold War ended, the flow of free highly subsidized arms have continued to pour into the region from numerous legal arms producers such as China, Iran, Russia, and Ukraine, France, Germany, Italy, the United Kingdom and the US are known as the major legal sources of weapons to African. The flow of small arms into the Horn of Africa where there has been conflicts has been a ready market for the arms, is responsible for the devastating impact on the governments such as in Ethiopia (1991),Rwanda (1994), Somalia (1991), and Uganda (1979 and 1986), among others. Some African countries that have added to the supplier of weapons to rebels and private dealers in countries include such countries as Sudan which supported insurgents in Ethiopia, Eritrea, and Uganda; Uganda, Eritrea, and Ethiopia which supported the Sudanese opposition in the South; and Eritrea and Ethiopia, due to their border conflict supported the opposition groups in Somalia and rebel groups operating in each other's countries. There is illicit trade in small arms in Africa and the main suppliers are known to be Russia and China (WCC, 2012; Stohl, 2010; African Union, 2001).

In South Africa, although it is not possible to know exactly the number of illegal weapons that are in circulation in, it is estimated that it ranges between 400,000 to eight million. The years between 2004 and 2006, it is reported that over 15000 registered firearms were reported lost or stolen each year, which further contributes to illegal weapons. The South African Police Service reported the loss or misplacing nearly 4,000 firearms and only about 10\% of these weapons are recovered between 2006 and 2007 (Oosthuysen, G., 1996). The South African arms industry perpetuate the presence of weapons and militarization of the Southern Africa, and the other African countries in the continent which is a ready market for the commodity, which is manufactures by the industries such companies as the Reutech, Cape Armoury, Tressitu Ammunition, Aserma, Republic Arms, Musgrave, Pretoria Metal Pressings and Littleton Engineering Works. These companies do not satisfy the demand for the commodity in Africa, so others are sourced from outside the continent like the US, where in 2006, transferred over US\$8.5 million worth of small arms into African countries. The value and sources of small arms trade is not possible to quantify because of its lack of transparency, however, the production of crude weapons adds to the supply of weapons to Africa, increasing the insecurity and conflicts. According to Schroeder, M.et al (2009) craft production in Ghana has the potential of yielding up to 200000 new weapons a year that could fuel criminal violence within Ghana, or be used in other regional conflicts and crimes 
The weapon held in the photograph was made in China

Source: Conflict Trends, 1, 2009

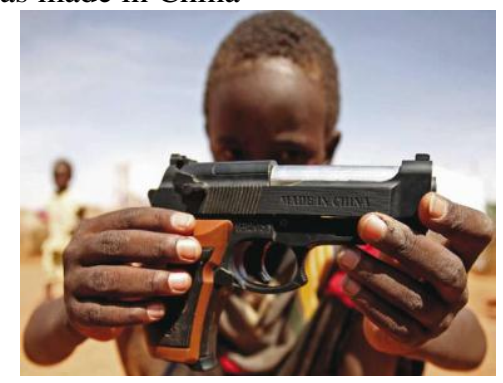

Small arms in the hands of rebels, fighters, war profiteers, which are often recycled from one country to another in Africa has been responsible for conflicts in such countries as Sudan, Somalia, Rwanda, Uganda, Angola, Sierra Leone, Democratic Republic of Congo and others (Religions for Peace. source: Conflict Trend: 1, 2009; WCC, 2012). There are also other sources of small arms such as black market where there are arms brokers, individuals or companies who evade international guidelines and national legislation to supply weapons to governments and armed groups, hence contributing greatly to criminality in Africa. They are able to work in the margins of national and international regulation, and face little regulation themselves. Unregulated brokers have been blamed for providing weapons for some of Africa's bloodiest conflicts, in Sierra Leone, Uganda, Congo and Sudan.

The intra-state armed conflicts in West African countries, such as Liberia, Sierra Leone and Nigeria's Niger Delta region, have however excercebate the demand as well as the expansion of gun trade in Africa. The conflicts in the Niger Delta which emerged in the 1990s was a result of conflict over oil which is mined by the multinational corporations and has given rise to bitter opposition from local community groups who engage in conflicts and proliferation of small arms and light weapons. In East African region the availability of small weapons has contributed immensely to insecurity in the region especially Kenya where there has been cattle rustling and armed criminals. In Nairobi suburbs an illegal pistol sells at less than US \$80, while ak-47s for under US\$140. The "leakage" of weapons, that are sneaked into Kenya and the neighbouring countries from Somalia, a country ruled by warlords, has spread insecurity all over to Kenya leading to underdevelopment of most o the northern part of Kenya. The availability of illegal arms also exacerbated urban crime and political violence. The smuggled weapons are secretly sold in the black market the proliferation of small arms and light weapons is evident among the pastoralists, who are in possession of sophisticated weapons in North and NorthEastern Kenya has also increased insecurity and conflicts in the cattle-rustling region, and loss of lives. Arms Survey found out that the price of an AK-47in Kenya costs Kshs. 25,000 or (\$385) in the North Rift, 35,000 Kenyan shillings (\$540) in Marakwet District, and up to 50,000 Kenyan shillings (\$770) in East Pokot district (Stohl, R., 2010; UNODA).

\section{Factors for Proliferation of Small Arms and Light Weapons}

Proliferation of small arms and light weapons has been enhanced by several factors. One $\mathrm{f}$ the factors is the fact that SALW are relatively cheap and many people can easily afford to own one. The AK-47 an Kalashnikov family of assault rifles, produced in some 29 countries and cost as little as $\$ 200$ new, or the price of a chicken, the second hand is much less after the Cold War(UNICEF,2007). Ukraine had huge reserves of arms and ammunition, a stockpile of excess weapons of over 2.5 million tons of which were sold off and $\$ 32$ billion worth of armaments between 1992 and 1998 were either lost or stolen. According to UNDP (2002) small arms are cheap to purchase. In 1999 it was reported in Uganda that an AK-47 assault rifle was bought for the price of chicken Neild (2002), while at a Russian factory it sells at \$240, The AK-47, much coveted for its firepower and simplicity. In some places of Africa with many suppliers, it can be bought at $\$ 30$ (Controlarms, 2006) and Angola could be bought between 13 to 20 USD, according to the UN, it could be procured for as little as six US Dollars or traded for a chicken or a sack of grain (UNICEF 2007). The availability and cheapness of SALW in Africa is due to the fact that at least 12 African countries are low scale producers such as Nigeria, Burkina Faso, Namibia, Kenya, South Africa, Uganda, Zimbabwe, Cameroon, Sudan, Tanzania, Guinea and Ethiopia, which are produced for use by the country's military, police and other security personnel (Bourne, 2007, cited by Ngang, C.K., 2007 ).The SALW are portable and can be easily carried from one place to another ,even by children. They can easily be disguised as cargo or clothing and not conspicuous; hence can easily pass unnoticed by the police security checks only to be noticed when it is already in the country.

The SALW require little training and expertise to operate it and any individuals, children and combatants who are given to use require no assistance once shown where to start it off (UNDP, 2002, Trend 1, 2009). The porous boundaries which have not fence or wall to separate the countries have contributed 
immensely to the ease of movement of SALW through countries. The borders were poorly drawn by the colonialists who at some locations separated families to belong to different countries. Some countries have boundaries that are too long for instance the border of Sudan, DRC and Chad, stretch over several kilometres such that a country is not able to man every activity at the border, and therefore SALW are easily smuggled into the country, causing more insecurity boundaries (Controlarms, 2006, Stohl \&Hogendoorn,2010). The proliferation of SALW is also due to the fact that they are highly lethal and can operate at a terrifying accuracy even by a single rebel. The automated SALW can release about 600 rounds per minute at a range of 800 to 1,000 meters, causing terror to a wide community. (Controlarms, 2006). Another factor which enhances the proliferations is that there is inadequate security measures in many countries of Africa as well as weak institutions that are responsible for security, have made the environment conducive for the arms to thrive (WCC,2012). The manufacturers of the SALW want a ready market which happen to be areas of conflict, and would like to sell the commodity to a ready market, which can be combatants, rebels or any gang that may want to terrorize the citizens. So the super powers refused to sign convention on prohibition of the sale of SALW, hence more proliferation of arms.

\section{Effects of SALW in Africa}

According to UN Security Council "The destabilizing accumulation and uncontrolled spread of small arms and light weapons in many regions of the world increases the intensity and duration of armed conflict, undermines the sustainability of peace agreements, impedes the success of peace building, frustrates efforts aimed at the prevention of armed conflict, hinders considerably the provision of humanitarian assistance and compromises the effectiveness of the Security Council discharging its primary responsibility for the maintenance of international peace and security" (United Nations 2002: 31). Indeed the fact that weapons are available in the hands of rebels and combatants, impedes the alternative conflict resolution strategies and instead, increases insecurity and further protracted conflict in the country as well as frustrating efforts of peacekeeping and peacebuilding operations in rebuilding and reconstructing of the societies that have been devastated by conflict (Sunday E., 2011; Stemmet,2001) .Man-portable Air Defense Systems (MANPADS), which are light weapons that are commonly referred to as shoulder-fired anti-aircraft missiles, when in the hands of criminals, terrorists and other non-state actors, also pose a potential danger to commercial aviation around the world( http://www.dtra.mil). In 2005, approximately 1.4 million people in northern Uganda regions such as, Gulu and its environs, were displaced by war .Many children are also orphaned and forced to work at an early age and become heads of households (Arms control 2006).

Small Arms and Light Weapons that are easily available in the hands of rebels, criminal gangs, and those not legally authorized to possess them, have been a source of insecurity in the civilians in the region. It estimated that more than 1,000 lives are lost each day to violence of SALW (Religions for Peace, 2004) has caused loss of lives to millions of people, injury, maimed individuals and misery to the community. Michael Renner, cited by Sunday E,(2011) small arms alone has caused havoc in Africa where an estimated 5,994,000 suffered fatalities in the last 50 years and another 30,000 people killed each year. This is a violation of human rights, for instance freedom to live and freedom from slavery. The threat of use of small arms economy of the victims lacks far behind because the people are in constant fear and insecurity and therefore fails to engage in economic and gainful activities. Many flee their homes as refugees and internally displaced and migrants crossing the border into the neighbouring countries, as well as interruption of humanitarian assistance. The Internal Displacement Monitoring Centre estimates that, in 2007, an estimated 12.7 million people were living as IDPs in Africa (Religions for Peace 2004; IDMC http//www.un.org)

World Bank found that the use of small arms by rebels and criminals negatively affect the economy which includes the private wealth being divested which doubles during an armed conflict, and that the cost of civil war is approximated at $60 \%$ of its annual gross domestic product. An armed conflict is very expensive and drains a country's resources and thus impoverishes the populace. In Africa for instance cost of armed conflicts costs some \$18 billion annually International Maritime Bureau's Piracy Reporting Centre (PRC) reported that about 293 incidences of piracy which occurred globally indicated that 111 were experienced at the coast of Somalia especially at the Gulf of Aden, while 40 occurred off the coast of Nigeria (Conflict Trend 1, 2009). The proliferation of small arms has contributed immensely to the rise and effectiveness of piracy which has seriously threatens Africa and the international community as well as the International shipping interests which have been tremendously affected. A study conducted by Oxfam (2007) found out that in the Democratic Republic of Congo during conflicts in the years from 1990 the 23 countries in Africa that were engaged in conflict experienced a sharp drop in their economies by an approximately $15 \%$ per year, that is a cost of US\$18 billion annually and the total loss of US\$284 billion to African economies (Stemmet, 2001). Kenya has been a victim of piracy and has lost an estimated US\$150 million in ransoms paid to the pirates off the East Africa coast.

The proliferation of small arms and light weapons due to their availability and ease in operation, maintenance and easy portability has given rise to child soldiers where the rebels give children weapons to 
carry and use them in fighting. There is an estimated 300,000 children who are involved in more than 30 conflicts worldwide, another two million children have been killed in conflict, over one million orphaned, over six million have been seriously injured or maimed, permanently disabled and over ten million have been left with serious psychological trauma, $40 \%$ of theses child soldiers are girls who serve as "wives" to the combatant (UNICEF,2007). The small arms are used in armed criminal violence, for instance in South Africa the criminal armed violence is responsible for injuries from gunshot estimated at $46 \%$ of violence related deaths (arms survey, 2012; controlarms, 2006).The small arms which remained after the conflicts in Mozambique, Angola, Somalia, Liberia, Sudan, Sierra Lone including the licensed weapons that are stolen or lost, have played a major role in exacerbating crimes and armed violence. The continent is a major trans-shipment point for the international trade, as well as a major producer of local arms.

\section{Challenges to reduction of SALW}

Control of SALW in the member countries through protocol has become a challenge (controlarms2006). This is mainly because the Firearms Protocol is inadequate in covering certain small arms or state-to-state transfers if one of the states' national security interests are at stake (UNODA 2006'). Membership to the Protoco is not universal; neither does concern with the issues of not address small arms in the context of armed conflict and post conflict situations. Many States are not in agreement as to what steps to be taken to counter illicit small arms trade and therefore opposes the UN legal framework on SALW trade because it is their national security. Most of these states would not support arms control, but support mainly the illegality of SALW (Stemmet, 2001; Stohl, 2010; Conflict Trend, 2009). Another challenge to control of SALW is that the UN Program of Action was indeed only a program of action thus weak and unsuccessful, that is, it was politically binding but not legally. The weapon producers like the USA, China, India, Israel, Russia, Egypt did not welcome the idea of arms control because it would interfere with their lucrative business. These superpowers did not agree on interpretation of ammunition possession, "responsibilities of state', prohibition of transfers to those who are not state actors and global guidelines for SALW transfers (UNODA, Stemmet, 2001, controlarms, 2006) .The United States opposes the restriction on transfer of weapons because it violates the US "the rights of the oppressed to defend themselves against tyrannical and genocidal regimes.". USA also opposes controls on small arms ammunition as well as of arms possession by the civilians because it may interfere with the constitutional rights of U.S. citizens to bear arms (Religions for Peace, UNODA, WCC, 2012, Conflict Trend, 2009).

Many African countries have supported these international initiatives, compliance is often weak. A lack of resources undermines the response to the small arms problem and the ability to implement international agreements and obligations. Programmatic initiatives - such as DDR, weapons collection, destruction programmes and physical stockpile security management (PSSM) - are expensive, and may require bilateral or multilateral support (Conflict Trends, 2009). Indeed, UN agencies, the European Union and the US are among the largest supporters of African small arms programmes. The US, for example, has provided assistance to 21 sub-Saharan African countries since 2001 by assisting in the marking of weapons, destroying surplus small arms and man-portable air defense systems (MANPADS), and improving stockpile security. Small arms pose a great challenge to the governments despite several international and regional conventions that have been signed, among them is the 2001 UN Programme of Action to Prevent, Combat and Eradicate the Illicit Trade in Small Arms and Light Weapons in All its Aspects. In Rwanda, for instance, the former combatants are still undergoing training because there were neither demobilization, nor reintegration in to civil society, hence security threats to the country (arms survey, 2010; controlarms, 2012' stemmet, 2009).
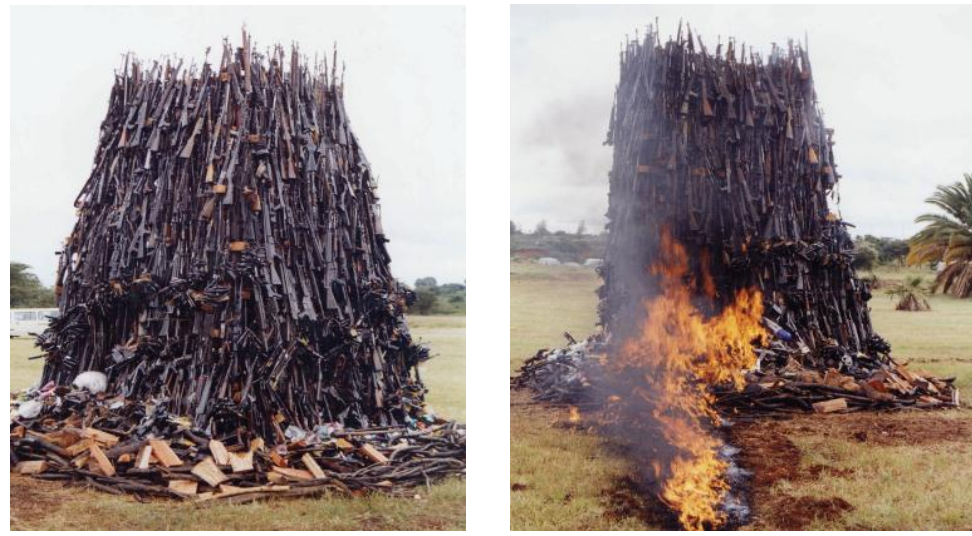

SOURCE: Best Practice Guidelines for the Implementation of the Nairobi Declaration and the Nairobi Protocol on Small Arms and Light Weapons 
Andre Stemmed (2001) Small Arms and Light Weapons from other arms control issues, thus complicating their legal regulation: a lack of institutional mechanisms, while the few existing regimes aimed at control are relatively weak the distinction between legitimate users of this category of weapons, the security forces of states, and the illicit proliferation that takes place outside the state system, is a problem that must be addressed; consequently, the solution does not lie in outlawing such arms, as was the case with landmines;

\section{Interventions and Initiatives to control SALW Africa}

The UNITED NATIONS General Assembly (April 2013) approves the first world body that regulates the multi-billion international arms trade, which will help keep illicit weapons out of the hands of terrorists, insurgent fighters and organized crime. Many countries, including the United States, control arms exports, approved for the first time an international treaty regulating the estimated \$60-billion global arms trade. The treaty prohibits exports of conventional arms if used to attack civilian, schools and hospitals (www.un.org).

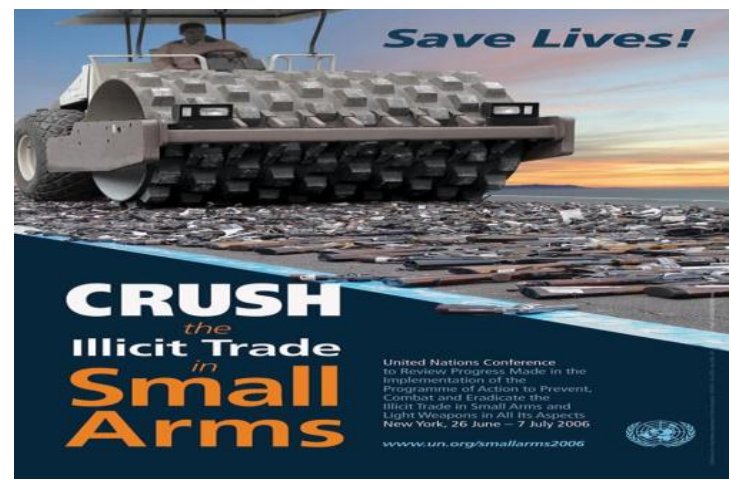

SOURCE http://www.un.org/events/smallarms2006/faq.html 30may 2013

In 2001, UN Program of Action (PoA) to Prevent, Combat and Eradicate the Illicit Trade in Small Arms and Light Weapons in All Its Aspects was the largest UN initiative, the program does not define the "illicit" arms trade, although most understand it to refer to trade that is contrary to the law of states and/or international law. The UN Instrument on Tracing Illicit Small Arms, adopted by the UN General Assembly in December 2005, builds on the minimum standards on marking, record-keeping, and cooperation in tracing of small arms that are contained in the UN Firearms Protocol and the program of action. It appeals to the states to mark all legally produced small arms with a code containing a unique serial number and information that identifies the country of manufacture and the manufacturer as well as keeping adequate records on small arms production and transfers and to cooperate in the tracing of illicit small arms recovered outside their country of production (controlarms2006; Conflict Trend January 2009).

In May 2001, the General Assembly adopted the UN Protocol against the Illicit Manufacturing of and Trafficking in Firearms, Their Parts and Components and Ammunition, known as the Firearms Protocol the legally binding Firearms Protocol entered into force in July 2005, and 60 states are party to it at present. It stipulates measures such as the criminalization of the illicit manufacturing of or trafficking in firearms and the strengthening of capacities to detect and investigate illicit transfers in the context of transnational organized crime. However ,The Firearms Protocol does not include some small arms or state-to-state transfers if one of the states' national security interests are at stake and also membership of the protocol is not universal, and it does not address small arms in the context of armed conflict and post conflict situations(arms survey, 2012; controlarms 2013)

The Bamako Declaration is an Africa-wide consensus which addresses the illicit proliferation, circulation and trafficking of small arms and Light Weapons. It is a politically binding control instrument which was adopted by the ministerial conference of member states of the defunct Organization of African Unity (OAU, now African Union (AU) in December 2000. The aim is to develop an African common position where all members agree on its terms on the illicit proliferation, circulation and trafficking of SALW and of the AU, to encourage the codification, marking, record-keeping and harmonization of legislation which governs the production, trading, brokering, importation, exportation and the licit possession and use of small arms and ammunition in the country governing imports, exports and the licit trade (Stemmet, 2001; conflict Trend 2009). The African Regions have also developed their own plans to address their domestic and specific small arms challenges where in East Africa is the Nairobi Protocol on the Prevention, Control and Reduction of Small Arms and Light Weapons in the Great Lakes Region and the Horn of Africa is legally binding, was adopted in April 2004 and entered into force in May 2005, which provides a framework for national small arms legislation and in the West African states, the Economic Community of West African States (ECOWAS)1998 is a 
politically binding Declaration of a Moratorium on the importation, exportation and Manufacture of Small Arms and Light Weapons, which was made legally binding in 2006.

The Southern Africa Development Community (SADC) Protocol on Firearms, Ammunition and Other Related Materials is a regional and legally binding instrument to increase control over the proliferation of small arms in Southern Africa(Ngang, 2007). This addresses the problem of proliferation of SALW include the Operation Rachel for collecting weapons and also Programme for Action which aims at combating illegal arms trafficking in Southern African states as well as the Southern African Development. Its main objectives are to prevent, combat and eradicate the illicit manufacturing of firearms, ammunition and other related materials, to promote legal uniformity and minimum standards in the manufacture, control, possession, import, export and transfer of firearms and ammunition and facilitate cooperation and exchange of information and experience on SALW issues in the Region and to ensure the standardized marking of firearms at the time of manufacture (Nairobi Protocol, stemmet 2009; UNODA).

\section{Conclusion}

The Small arms and Light Weapons (SALW) has placed Africa an arena of warfare, insecurity conflict and destruction. It has led to underdevelopment of Africa's economy, rendered people homeless and refugees and loss of millions of lives. Many countries are still counting their losses even with the many protocols and conventions signed to prevent the proliferation of SALW. Some producers of the weapons are making business out of other peoples' suffering and therefore are not willing to stop the use of SALW. The international conventions are being negotiated and several steps towards agreement on the provisions of the protocol is bearing fruit so that the world can be arms free, a place worth living without a threat of insecurity.

The African problems are left for Africans to solve for themselves yet the cause may not have been solely African. The companies that produce weapons know very well that the arms are used to destroy lives, yet they want to continue making profits. Many countries in the horn of Africa has been a region of restlessness and conflict, mainly because the arms are sneaked through some avenues from the manufacturers outside the continent. To stop war, we must stop the production of SALW, destroy all the stockpiles and make plowshares instead. There is need to take the African problems as our own in need of immediate attention so that our neighbours, the Sudan, Somalia, DRC, CAR, among others can live peacefully with the rest of the world and build a continent, develop our continent, make peace with the world.

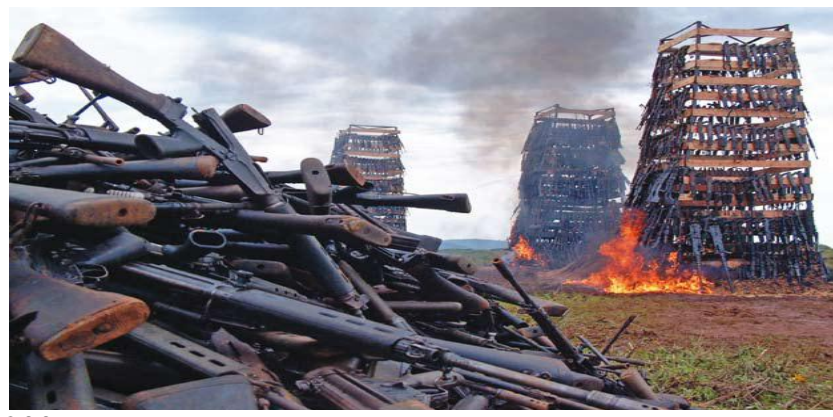

Source: Conflict Trend, 1.2009

Sierra Leone's disarmament programme resulted in the successful collection and destruction of thousands of weapons

\section{References}

[1]. Abdel-Fatau M. (2004) The Political Economy of Small Arms and Conflicts

[2]. http://unpaul.un.org/intradoc/groups/public/documents/idep/unpan002406.pdf.accessed on 25th April, 2013

[3]. Anders, H., and (2007) The UN Process on Small Arms: All Is Not Lost accessed from htt://www.armscontrol.org/ act/2007

[4]. Africa Union The Peace and Security Agenda, accessed on 20 April at http://www.africaunion.org/root/au/AUC/Departments/PSC/Small_Arms.htm

[5]. Africa Recovery, Vol. 15, No. 4, December 2001

[6]. The role of SALW in conflict and insecurity in sub-Saharan Africa

[7]. Best Practice Guidelines for the Implementation of the Nairobi Declaration and the Nairobi Protocol on Small Arms and Light Weapons accessed on $30^{\text {th }}$ May 2013 pdf

[8]. Conflict Trend, 1. (2009) ACCORD, South Africa

[9]. Control Arms Briefing Note, (2006) The AK-47: The World's favourite killing machine, June 2006, retrieved on13 ${ }^{\text {th }}$ May, 2013 http://www.controlarms.org/find_out_more/reports/AK_47.pdf

[10]. Eavis, P., (2002) SALW in the Horn of Africa and the Great Lakes Region: Challenges and Ways Forward Spring 2002 Volume IX, Issue 1

[11]. Office of the Special Representative of the United Nations Secretary-General for the Great Lakes Region(2003)Peace, Security, and Governance in the Great Lakes Region. 
[12]. Mazrui, A., (1986) http://www.globalissues.org/article/78/small-arms-they-cause-90-of-civilian-casualties accessed on 20th April, 2013

[13]. Mpyisi, K., (2009) IDEA

[14]. The Nairobi Protocol For The Prevention, Control And Reduction Of Small Arms And Light Weapons In The Great Lakes Region And The Horn Of Africa,2005

[15]. Ngang, C., K., (2007) Small Arms and Light Weapons, Africa's True WMDS: The Role of SALW in Conflict and Insecurity in Sub-Saharan Africa.

[16]. Neild, R., (2002) The Dark Side of Social Evolution, London Anthem Press,

[17]. Njoroge, M., (2005) Small Arms And Light Weapons In Kenya.

[18]. Oosthuysen, G., (1996) Small Arms Proliferation And Control In Southern Africa Published by

[19]. The South African Institute of International Affairs (SAIIA) SAHA, 1996, with the assistance of The United States Institute of Peace (USIP)

[20]. Rachel Stohl and Doug Tutle (2009) The Challenges of Small Arms and Light Weapons in Africa .Conflict Trends Issue 1, 2009

[21]. Rachel Stohl and EJ Hogendoorn (2010) Stopping the Destructive Spread of Small Arms How Small Arms and Light Weapons Proliferation Undermines Security and Development. Accessed on $20^{\text {th }}$ May, 2013 from www.americanprogress.org

[22]. Religions for Peace 777 United Nations Plaza, 9th Floor, New York, NY 10017 accessed on $19^{\text {th }}$ May, 2013 from http://religionsforpeace.org/initiatives/violent-conflict/disarmament

[23]. Shah, A., (2006) http://www.globalissues.org/article/78/small-arms-they-cause-90-of-civilian-casualties accessed on 20th April, 2013

[24]. Sacha Journal of Environmental Studies, Volume 1 Number 2 (2011) pp. 55-80

[25]. Sunday, E., (2011) The Proliferation of Small Arms And Light Weapons In Africa: A Case Study Of The Niger Delta In Nigeria Sacha Journal of Environmental Studies, Volume 1 Number 2 (2011) pp. 55-80

[26]. Stemmet, A., 2001) Regulating Small Arms and Light Weapons The African Experience Published in African Security Review Vol 10 No 3, 2001 accessed on $20^{\text {th }}$ March 2013

[27]. Small Arms Survey (2009) Shadow of War (Cambridge: Cambridge University Press, 2009).

[28]. Small Arms and Light Weapons http://www.international-alert.org/our-work/small-arms-and-light-weapons-salw Accessed on 15th May, 2013

[29]. AU (February $25^{\text {th }}, 2013$ )AU-Regions Steering Committee Meeting On Small Arms And Light Weapons, And Disarmament Demobilization And Reintegration Ends In Addis Ababa

[30]. Berman, E. G. \& Kerry., (2012) Regional Organizations and the UN Programme of Action on Small Arms (PoA) .Small Arms Survey Research Notes $\bullet$ Number $21 \cdot$ September 2012

[31]. UNICEF http://www.unicef/smallarms/exhibit Accessed on 25th May, 2013

[32]. UNDP, 2002, cited by Conflict Trend, 12009

[33]. UNODA Small Arms http://www.un.org/disarmament/convarms/SALW Accessed on 13th May 2013

[34]. UN Office for the Coordination of Humanitarian Affairs http://www.globalsecurity.org/military/library/news/2005/06/mil-050624-irin01.htm 12th May 2013.

[35]. UNITED NATIONS General Assembly (2001) $5^{\text {th }}$ session on Resolution adopted on Protocol against the Illicit Manufacturing of and Trafficking in Firearms, Their Parts and Components and Ammunition, supplementing the United Nations Convention against Transnational Organized Crime. Accessed on 30thMay, 2013 from www.un.org

[36]. WorldCouncil of Churches Communications (2012) Africa struggles with impact of small arms proliferation accessed from http://www.pcusa.org/news/2012/12/7/africa-struggles-impact-small-arms-proliferation. On 12th May 2013

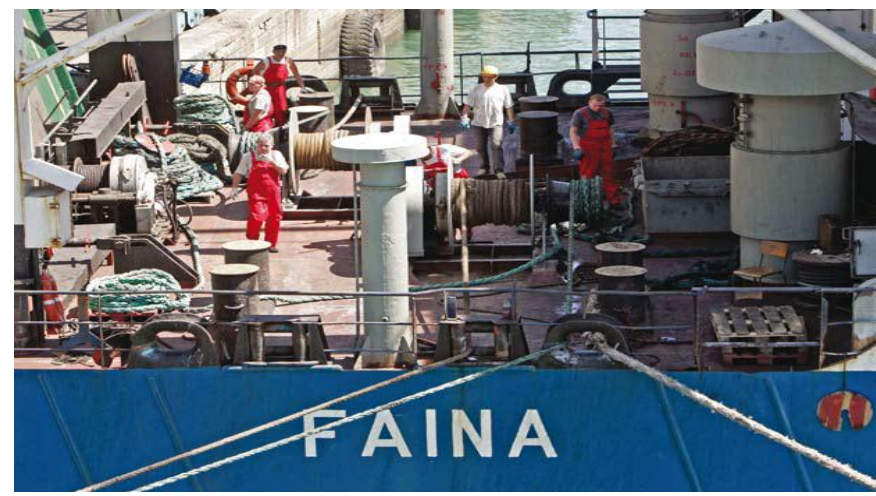

SOURCE: Conflict Trends 1, 2009: In September 2008 approximately 50 gunmen boarded and captured the MV Faina, a Ukrainian ship loaded with tanks, small arms and light weapons 